\title{
Pengembangan Sistem Rekruitmen Karyawan Perusahaan Mitra UPT Kewirausahaan Dan Pengembangan Karir Universitas Lampung
}

\author{
${ }^{1}$ Destian Ade Anggi Sukma , ${ }^{2}$ Machudor Yusman, ${ }^{3}$ Favorisen R. Lumbanraja, ${ }^{4}$ Rico Andrian \\ 1,2,3,4 Jurusan Ilmu Komputer FMIPA Universitas Lampung \\ Jl. Prof. Dr. Soemantri Brodjonegoro No. 1 Bandar Lampung 35145 \\ ${ }^{1}$ destiansukma29@gmail.com, ${ }^{2}$ machudoryusman@yahoo.com, \\ ${ }^{3}$ favorisen.lumbaranraja@fmipa.unila.ac.id, ${ }^{4}$ rico.andrian@fmipa.unila.ac.id
}

\begin{abstract}
Recruitment is the process of finding and the best-qualified candidate work in a company or agency. There are various recruitment methods such as via employee recommendations, university collaboration, job vacancy, and jobsfair. In this paper an online company employee recruitment will be made using the black box testing method with the Equivalence Partitioning technique and the Likert scale. The data is taken from company users and job seekers. System displays job vacancies in accordance with the minimum level of education, gender and applicant's GPA. Job seekers fill out the Curriculum Vitae (CV) on the system as a company assessment for acceptance of applicants. The system can also provide announcements for applicants who have successfully passed a company. The system has been tested with black box testing with technique Equivalence Partitioning and get valid results for each test case, and for testing using a Likert scale gets very good results with a value of $87.05 \%$.
\end{abstract}

Keywords: Recruitment, job vacancy, companies, CCED, Black Box Testing

\section{Pendahuluan}

Dalam bidang pekerjaan, khususnya pada bidang rekrutmen, perusahaan sebagai penyedia lapangan pekerjaan dapat memberikan peluang pencari kerja untuk mendapatkan pekerjaan yang diinginkan. Masalah dalam proses mendapatkan informasi lowongan pekerjaan dapat dibantu menggunakan teknologi. Salah satu contoh teknologi yang dapat membantu pencari kerja untuk mendapatkan informasi lowongan pekerjaan adalah dengan menggunakan rekrutmen secara online. Rekrutmen secara online dapat mempermudah pencari kerja dan perusahaan untuk mendapatkan informasi lowongan pekerjaan secara langsung dari perusahaan tersebut.

Rekrutmen online atau dikenal dengan e-recruitment adalah sebuah proses perekrutan tenaga kerja secara online menggunakan media internet sebagai fasilitas pendukung utama dengan tujuan agar proses tersebut lebih mudah. E-recruitment menampilkan lowongan pekerjaan yang dibuat oleh perusahaan beserta dengan minimal jenjang pendidikan, jenis kelamin yang dibutuhkan dan waktu berakhir lowongan pekerjaan tersebut. Berdasarkan uraian tersebut, maka perlu dibangun pengembangan sistem rekrutmen online yang dapat digunakan untuk memudahkan pencari kerja dan perusahaan. serta untuk mencegah informasi lowongan yang tidak benar.

\section{Metodologi Penelitian}

Penelitian dilakukan di Gedung Ilmu Komputer Universitas Lampung dan UPT Kewirausahaan dan Pengembangan Karir Universitas Lampung. Penelitian ini dilakukan dengan menggunakan beberapa alat untuk mendukung dan menunjang pelaksanaan penelitian. Alat pendukung yang digunakan adalah sebagai berikut: 


\title{
2.1 Perangkat Keras (Hardware)
}

\author{
1. System Manufacturer: ASUS \\ 2. Processor : Intel® Core TM $15-7200 \mathrm{CPU} @ 2.5 \mathrm{GHz}$ \\ 3. Memory : RAM 8.00GB \\ 4. Harddisk: $1 \mathrm{~TB}$
}

\subsection{Perangkat Lunak (Software)}

1. Sistem Operasi WindowS 10 Home N 64 Bit

2. Star $U M L$

3. JustInMind

4. Atom

\section{2.3 Metode Penelitian}

Metode pengembangan yang digunakan dalam penelitian ini adalah metode Waterfall. Tahap yang dilakukan yaitu wawancara, desain, implementasi (coding), pengujian dan pemeliharan sistem (maintenance). Tahapan yang dilakukan ditunjukkan pada Gambar 1.

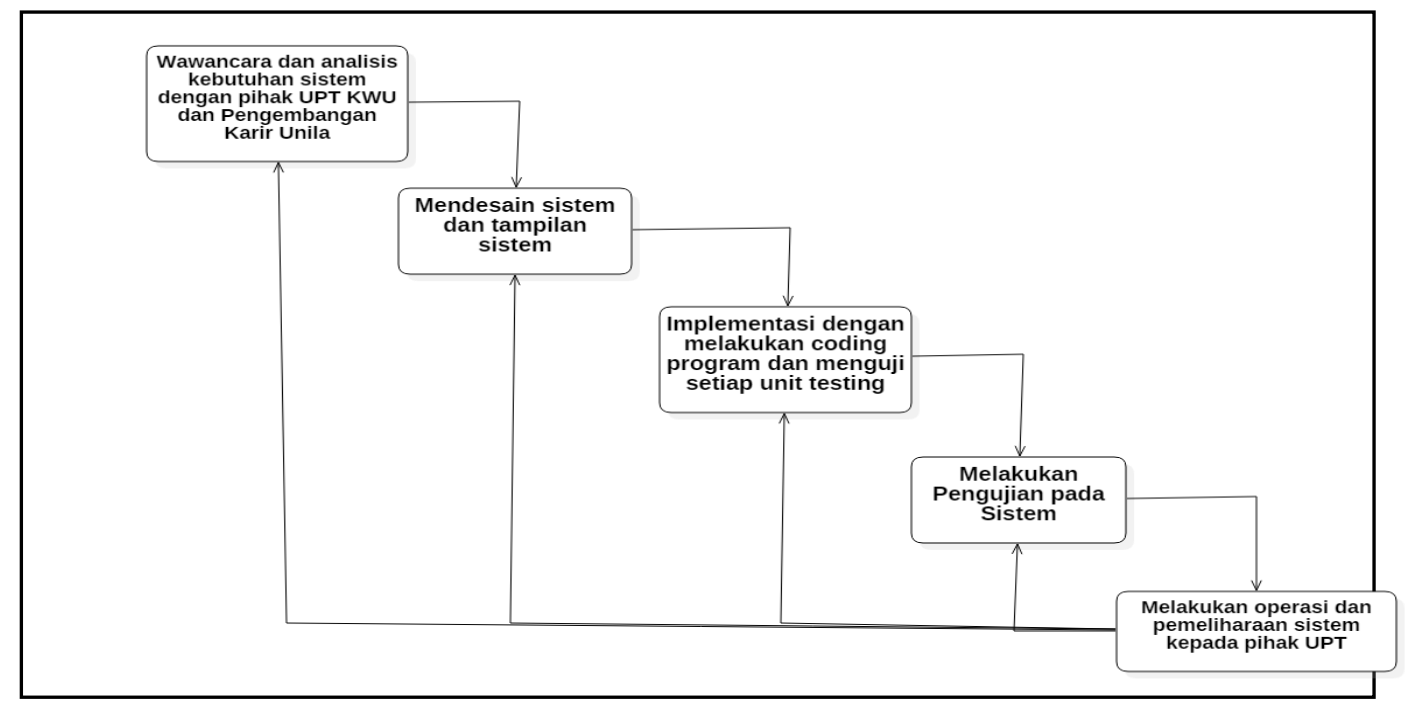

2 Gambar 1. Metode Waterfall Pengembangan Sistem Rekruitmen Karyawan Perusahaan Mitra UPT Kewirausahaan dan Pengembangan Karir.

Tahap-tahap pengembangan sistem yang dilakukan pada Waterfall adalah:

\subsubsection{Requirement definition}

Pada tahapan requirement definition (analisis), pengembang sistem (developer) melakukan komunikasi dengan pemilik usaha untuk menentukan kebutuhan yang dikembangkan ke dalam sistem yang dibuat.

\subsubsection{System design}

Di tahap design, Spesifikasi dari kebutuhan pengguna dipelajari, dan dianalisis. Setelah analisis kebutuhan sistem selesai, dilanjutkan dengan desain sistem yang dibuat. Desain sistem dapat membantu dalam menentukan hardware dan sistem persyaratan yang membantu dalam mengembangkan sistem ini.

\subsubsection{Implementation}

Pada tahap ini, analisis dan desain mulai diimplementasikan ke dalam coding program. Setelah tahap coding selesai dilakukan, pengembangan sistem melakukan tahap verification atau pengujian sistem. Pengujian sistem sangat diperlukan untuk mencari kesalahan dan kegagalan dalam tahap coding program. 


\subsubsection{Integration and testing}

Seluruh unit yang dikembangkan dalam tahap implementasi diintegrasikan ke dalam sistem setelah pengujian yang dilakukan masing-masing unit. Setelah integrasi seluruh sistem diuji untuk mengecek setiap kegagalan maupun kesalahan.

\subsubsection{Operation and maintenance}

Tahap akhir dalam model waterfall. Perangkat lunak yang sudah jadi, dijalankan serta dilakukan pemeliharaan. Pemeliharaan termasuk dalam memperbaiki kesalahan yang tidak ditemukan pada langkah sebelumnya. Perbaikan implementasi unit sistem dan peningkatan jasa sistem sebagai kebutuhan baru.

\subsubsection{Usecase Diagram}

Usecase diagram pengembangsan sistem rekruitmen karyawan perusahaan mitra UPT kewirausahaan dan pengembangan karir universitas lampung terdapat 3 user yaitu pencari kerja/pelamar, perusahaan dan admin. Pelamar dapat mengisi data diri dan mengubah dalam bentuk CV, dapat mendaftar pada lowongan pekerjaan dan melihat pengumuman. Perusahaan dapat membuat lowongan pekerjaan, melihat data pendaftar. Admin dapat melihat data perusahaan, lowongan dan pelamar. Tampilan Usecase diagram ditunjukkan pada Gambar 2.

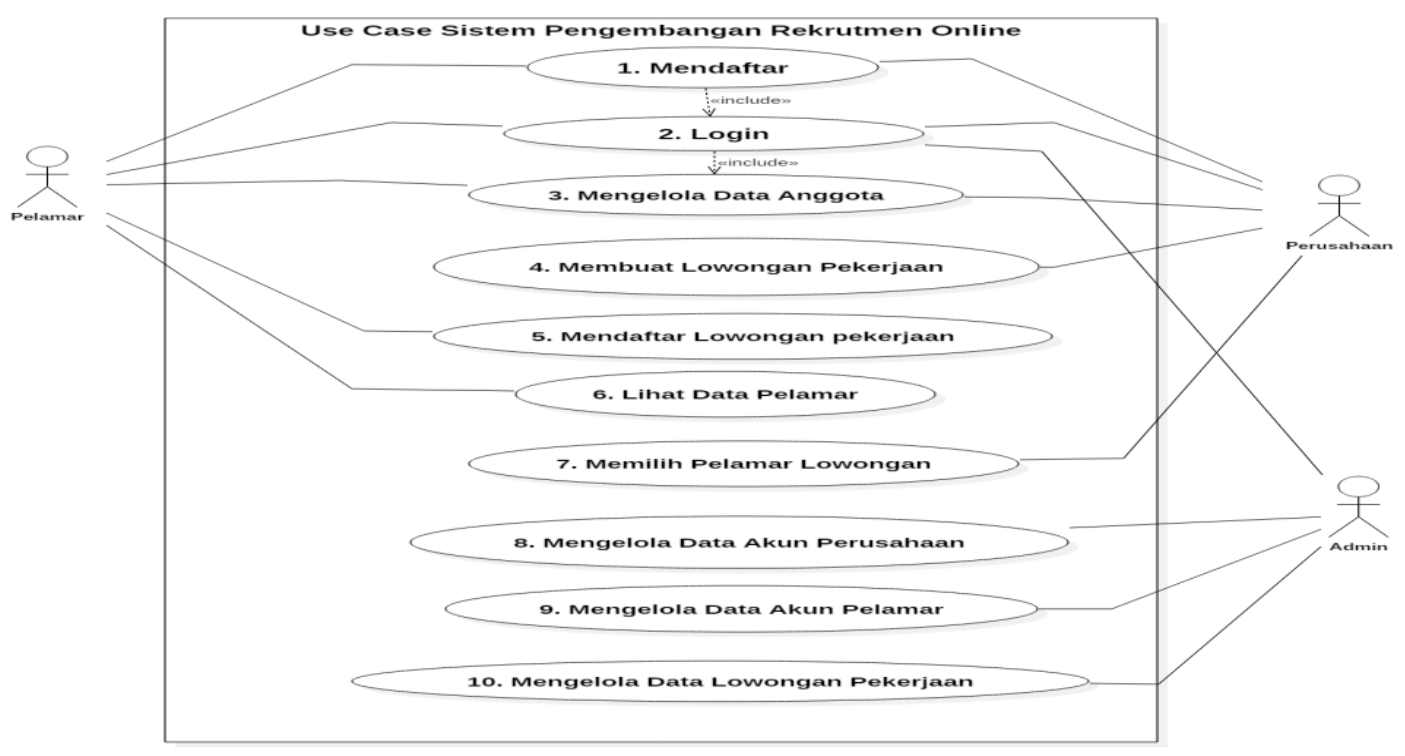

3 Gambar 2. Usecase Diagram Pengembangan Sistem Rekruitmen Karyawan Perusahaan Mitra UPT

\subsubsection{Class Diagram}

Kewirausahaan dan Pengembangan Karir.

Class diagram pengembangsan sistem rekruitmen karyawan perusahaan mitra UPT kewirausahaan dan pengembangan karir universitas lampung. Terdapat class perusahaan, pelamar dan lowongan. Pada setiap kelas digunakan id untuk menghubungkan data class dengan data class lain nya ditunjukkan pada Gambar 3. 


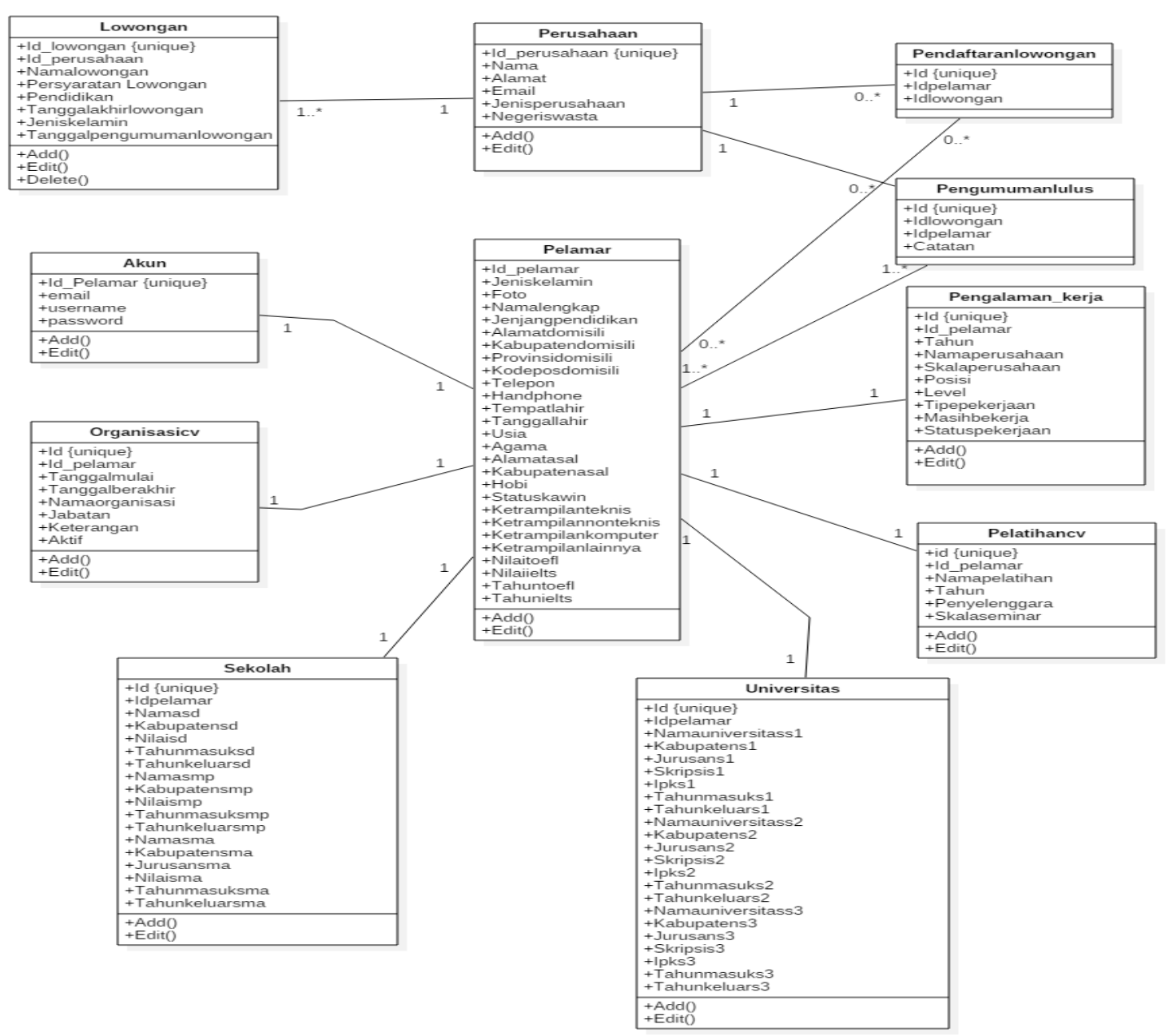

4 Gambar 3. Class Diagram Pengembangan Sistem Rekruitmen Karyawan Perusahaan Mitra UPT Kewirausahaan dan Pengembangan Karir.

\section{Pembahasan}

\section{Hasil}

Pengembangan sistem rekrutment online adalah sistem yang digunakan untuk menampilkan informasi lowongan pekerjaan yang telah dibuat langsung oleh perusahaan. Selain mendapatkan informasi lowongan pekerjaan pencari kerja dapat langsung mendaftar pada lowongan pekerjaan. Serta dapat menampilkan pengumuman pencari kerja yang lulus seleksi lowongan pekerjaan.

Sistem dibagi menjadi 3 user, yaitu Pencari Kerja, Perusahaan dan Admin.

\section{Implementasi}

Tahap ini dilakukan implementasi. Hasil tahap construction terdapat 3 user, yaitu Pencari Kerja, Perusahaan dan Admin. Berikut ini adalah tampilan dari user Pencari Kerja Perusahaan dan Admin:

\section{User Pencari Kerja}

Halaman pendaftaran 
Halaman pendaftaran berguna untuk mendaftarkan pengguna. Pengguna dapat memilih mendaftar sebagai perusahaan atau pencari kerja. Field menggunakan tipe text dan menggunakan field dropdown, halaman pendaftaran disajikan pada Gambar 4.

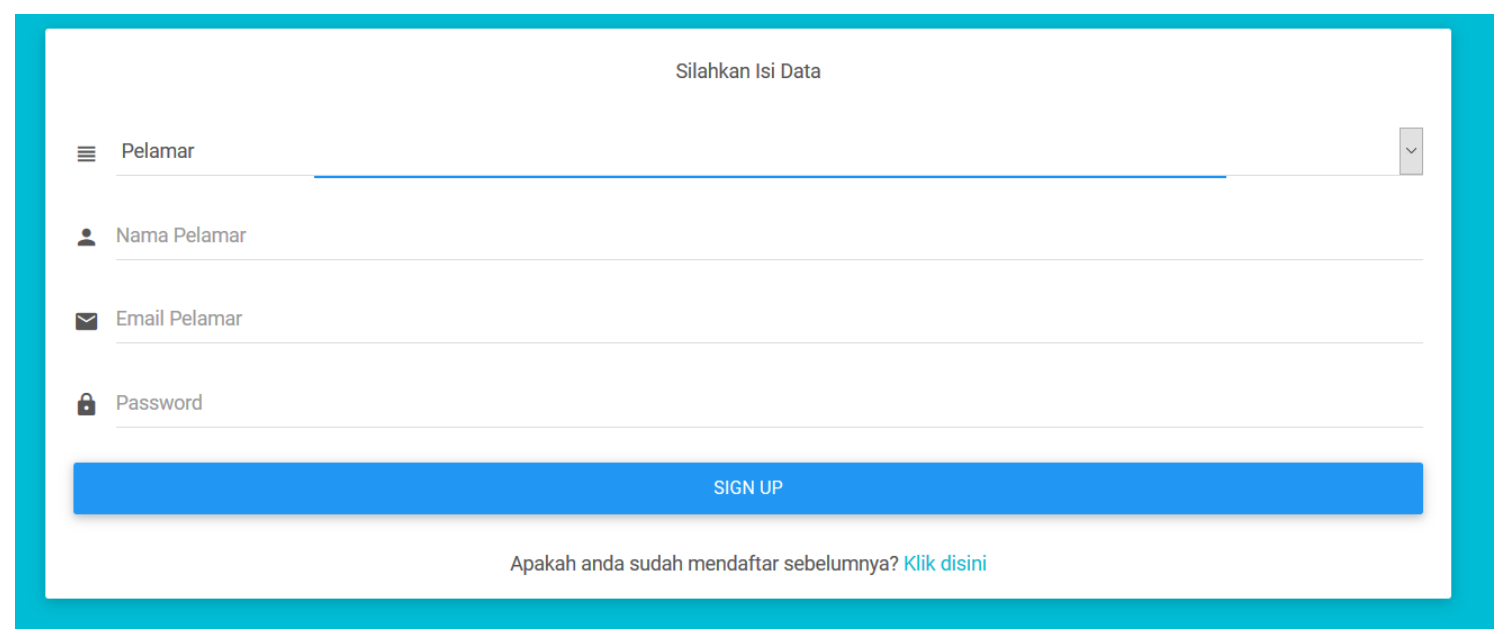

5 Gambar 4. Halaman Pendaftaraan.

Halaman Login

Halaman Login merupakan halaman yang digunakan untuk masuk ke tampilan sebagai user admin, pencari kerja atau perusahaan. Field yang digunakan pada email adalah tipe text dan untuk password menggunakan tipe password, halaman Login dapat dilihat pada Gambar 5.

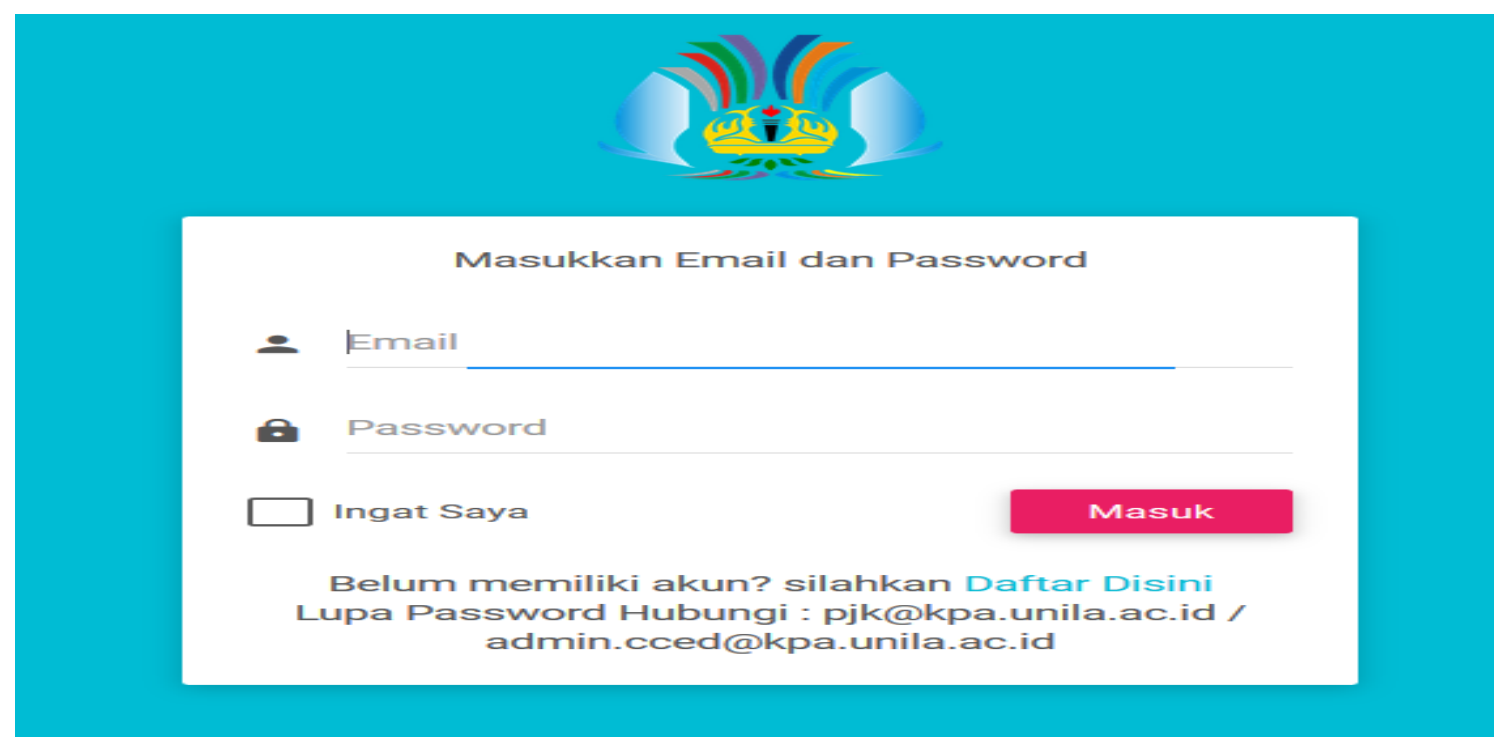

6 Gambar 5. Halaman Login.

Halaman Dashboard Pencari Kerja

Halaman dashboard Pencari Kerja menampilkan lowongan pekerjaan sesuai dengan jenis kelamin, jenjang pendidikan pelamar dan waktu berakhi lowongan. Terdapat informasi jumlah perusahaan, pencari kerja yang telah mendaftar pada sistem. Pengguna dapat melihat jumlah lowongan yang telah dibuat dan jumlah pengguna yang telah lulus. Pencari kerja dapat merubah akun pada field "Edit Akun" sebelum pencari kerja mendaftar pada lowongan yang telah dibuat, pencari kerja diharuskan mengisi CV pada field CV. Field daftar lowongan berisi lowongan yang telah didaftarkan oleh pencari kerja. Halaman Dashboard Pencari Kerja dapat dilihat pada Gambar 6. 
Vol 8 No. 1,2020

(C)2020 Ilmu Komputer Unila Publishing Network All Rights Reserved

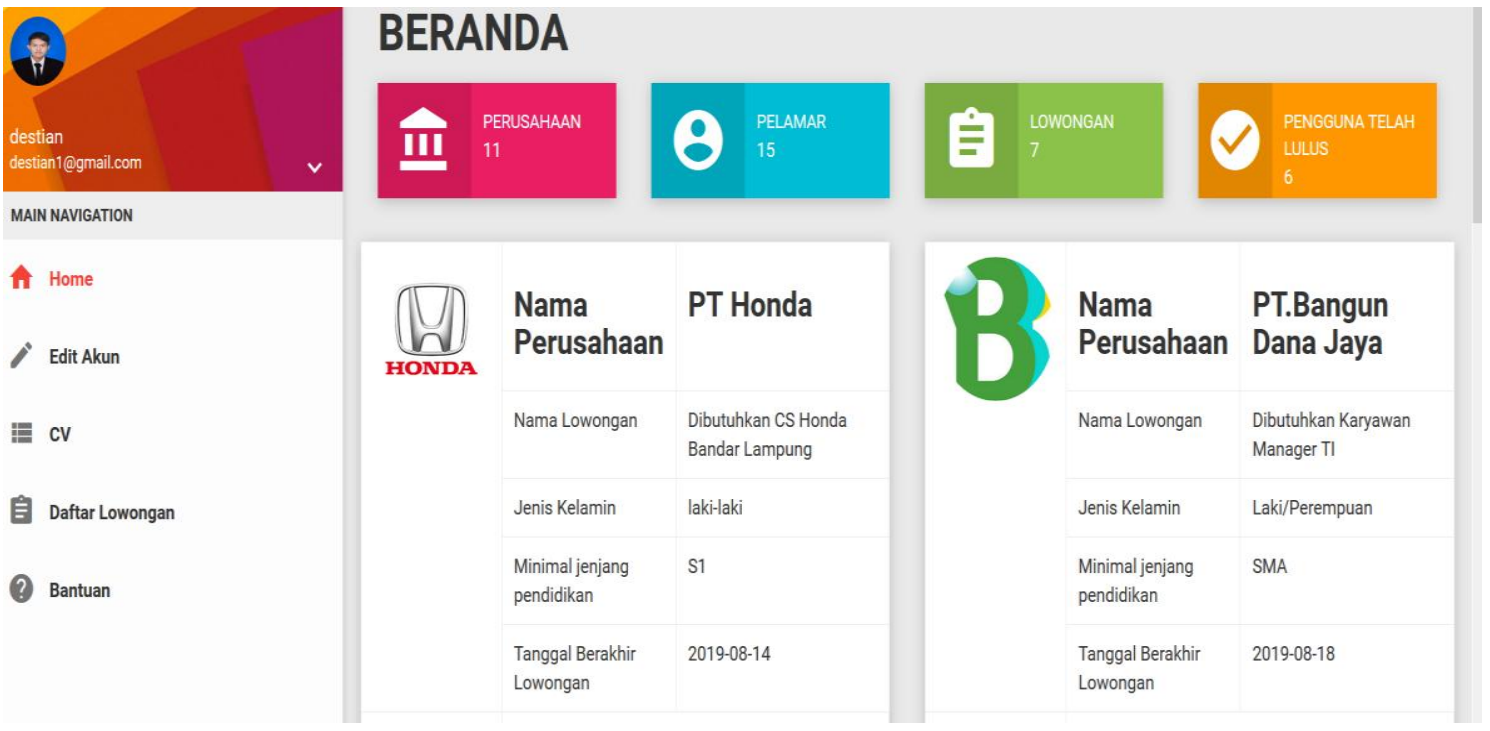

7 Gambar 6. Dashboard Pencari Kerja.

Halaman Commanditaire Vennootschapz (CV)

Halaman CV adalah halaman pada sistem untuk menampilkan biodata pencari kerja yang berguna sebagai nilai utama pencari kerja untuk mendaftar pada lowongan pekerjaan. Tampilan Commanditaire Vennootschap (CV) dapat dilihat pada Gambar 7.

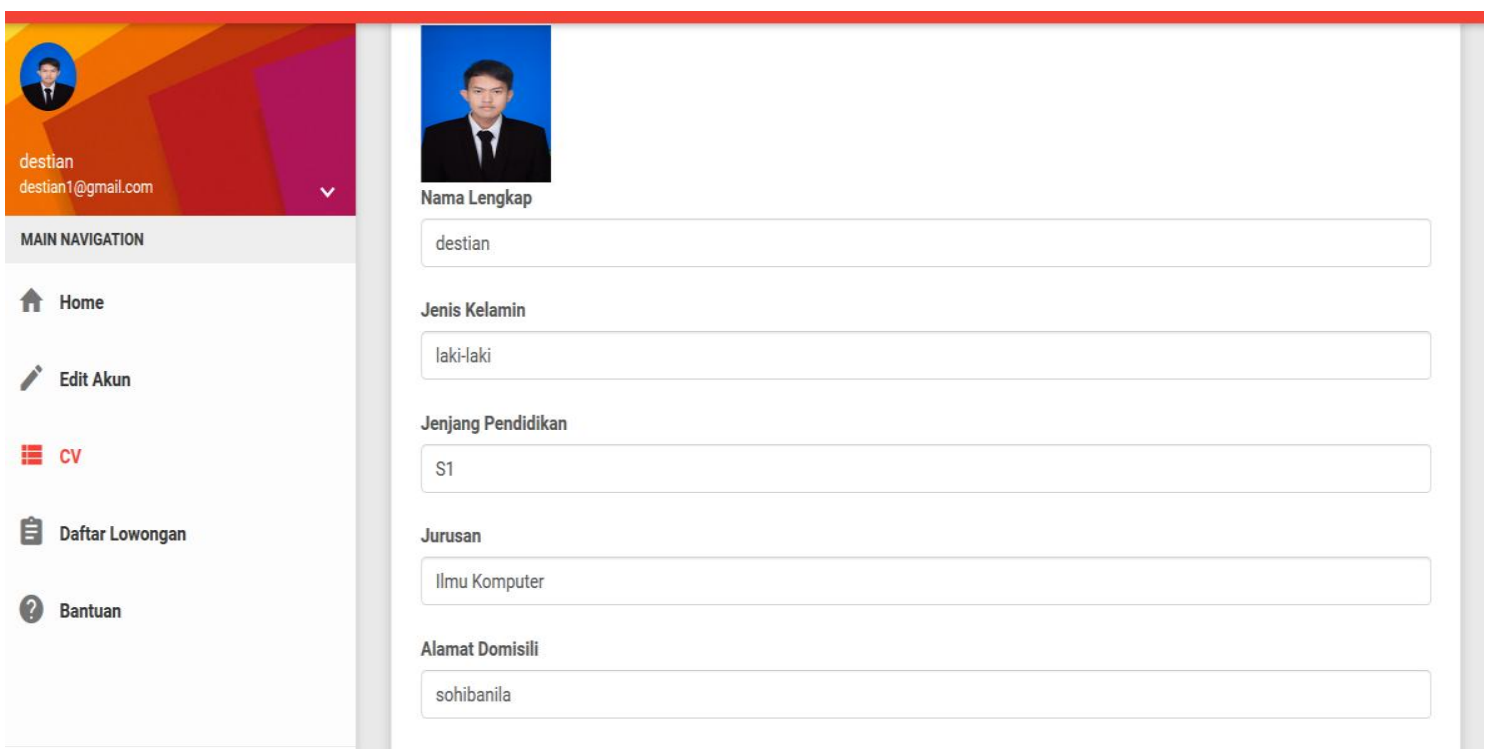

Gambar 7. Halaman Commanditaire Vennootschap (CV).

\section{User Perusahaan}

1. Halaman Tambah Lowongan Pekerjaan

Halaman Tambah Lowongan adalah halaman untuk membuat lowongan pekerjaan bagi perusahaan. Field nama lowongan menggunakan tipe text dan untuk jenis kelamin dan minimal jejngan menggunakan tipe dropdown. Tampilan Tambah Lowongan Pekerjaan dapat dilihat pada Gambar 8. 
Vol 8 No. 1 , 2020

(C)2020 Ilmu Komputer Unila Publishing Network All Rights Reserved

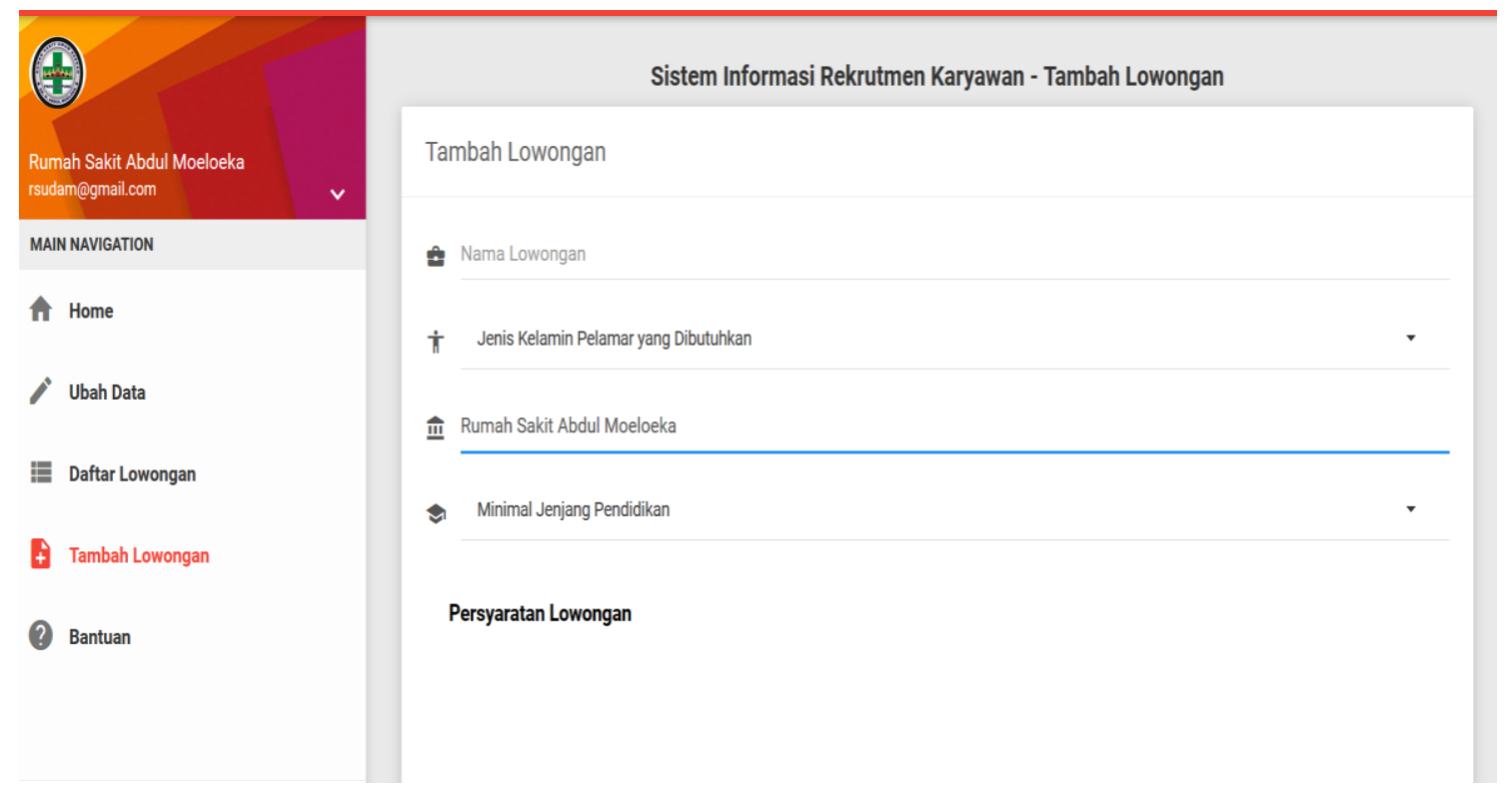

8 Gambar 8. Tambah Lowongan Pekerjaan.

2. Halaman Input Pengumuman

Halaman Input Pengumuman adalah halaman untuk perusahaan memilih pelamar kerja yang diterima pada lowongan pekerjaan yang telah dibuat. Tampilan Input Pengumuman dapat dilihat pada Gambar 9.

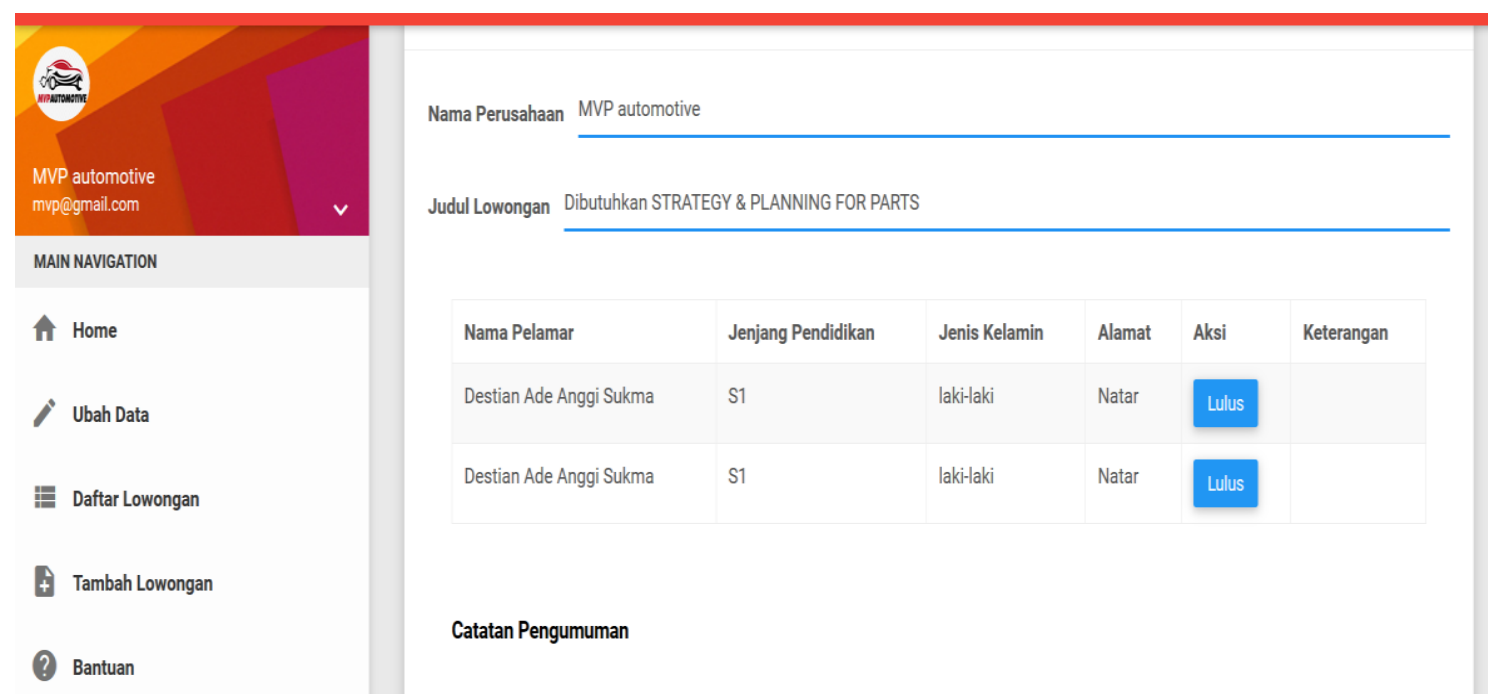

\section{User Admin}

9 Gambar 9. Input Pengumuman.

1. Halaman Lihat Data

Halaman Lihat data adalah halaman pada sistem untuk admin dapat melihat informasi perusahaan, pencari kerja dan lowongan pekerjaan yang terdapat pada sistem. Tampilan Lihat Data dapat dilihat pada Gambar 10. 


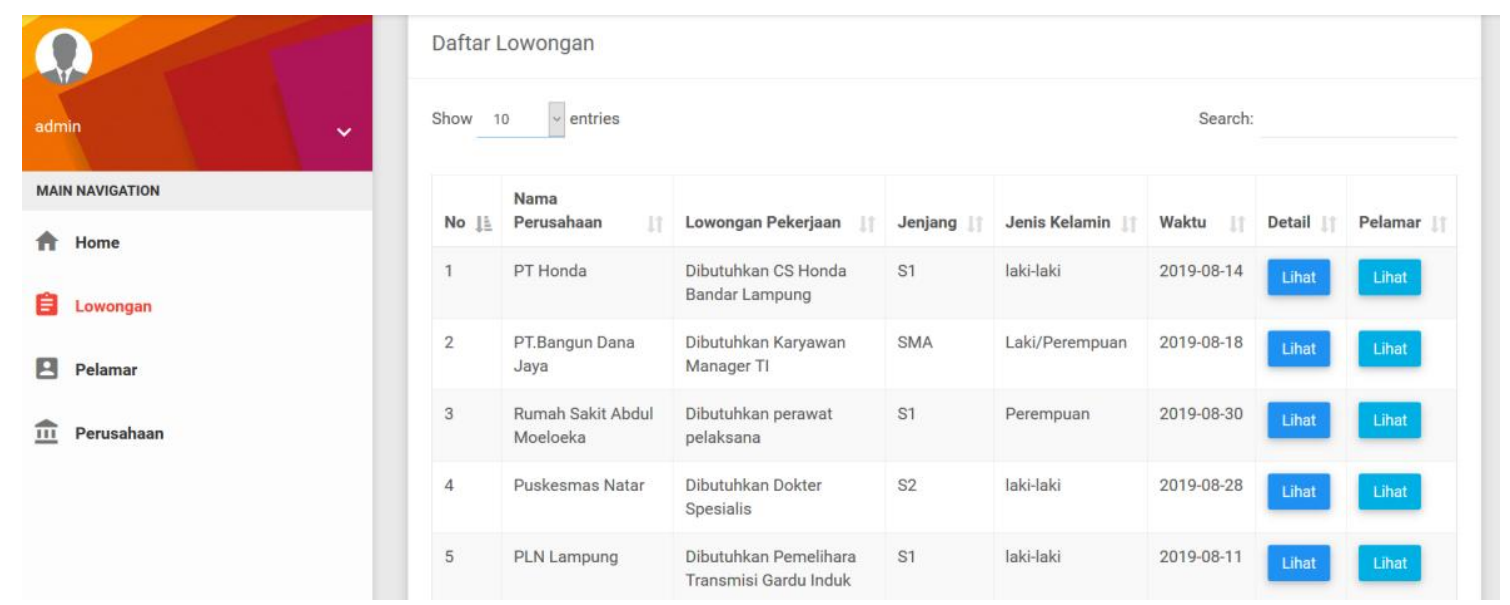

Gambar 10. Halaman Lihat Data (lowongan pekerjaan).

\section{Hasil Pengujian}

\section{Pengujian Fungsional}

Metode pengujian sistem yang digunakan adalah Blackbox Testing. Pengujian Blackbox merupakan pengujian yang berdasar kepada spesifikasi kebutuhan sistem dan tidak perlu memahami struktur pemrograman. Pengujian dilakukan dengan sudut pandang penguji yaitu end user. Pengujian dilakukan dengan membagi kelas uji menjadi 4, yaitu 1) Pengujian Skenario Security, 2) Pengujian Skenario Database, 3) dan Pengujian Skenario User Interface dan 4) Pengujian Fungsi dan Menu Aplikasi. Pengujian ini membuktikan bahwa aplikasi yang telah dibuat telah berjalan dan sesuai dengan yang diharapkan. Hasil pengujian fungsional pada aplikasi ini, semua fungsi dari menu aplikasi telah berjalan dan sesuai dengan yang diharapkan.

\section{Pengujian Non Fungsional}

Pengujian non fungsional dilakukan pada pengujian aplikasi dari atribut non fungsional. Pengujian non fungsional melibatkan pengujian perangkat lunak dan persyaratan yang non fungsional seperti tampilan (user interface), kinerja, dan kemudahan penggunaan aplikasi (user friendly).

Pengujian non fungsional pada Pengembangan Sistem Rekrutmen melibatkan 1 (satu) responden pada user Admin 5 (lima) responden pada user Perusahaan dan 10 (sepuluh) responden pada user Pencari Kerja. Diberikan 10 pertanyaan dengan skala 1-5, penilaian pada aplikasi dilakukan dengan pengambilan sampel secara acak. Penilaian dari responden tersebut akan mendapatkan penilaian secara langsung terhadap Pengembangan Sistem Rekrutmen. Berdasarkan pengujian yang telah dilakukan untuk user admin menggunakan teknik Equivalence Partitioning didapatkan bahwa seluruh menu dan fungsi didapatkan fungsi berhasil dengan yang diharapkan. Pengujian untuk user perusahaan dan pencari kerja menggunakan skala likert dan diperoleh rata-rata nilai persentase yaitu $87,05 \%$ dikategorikan bahwa sistem sangat baik. Berikut hasil skala likert pengembangan sistem rekuitment UPT Kewirausahaan dan Pengembangan Karir. 


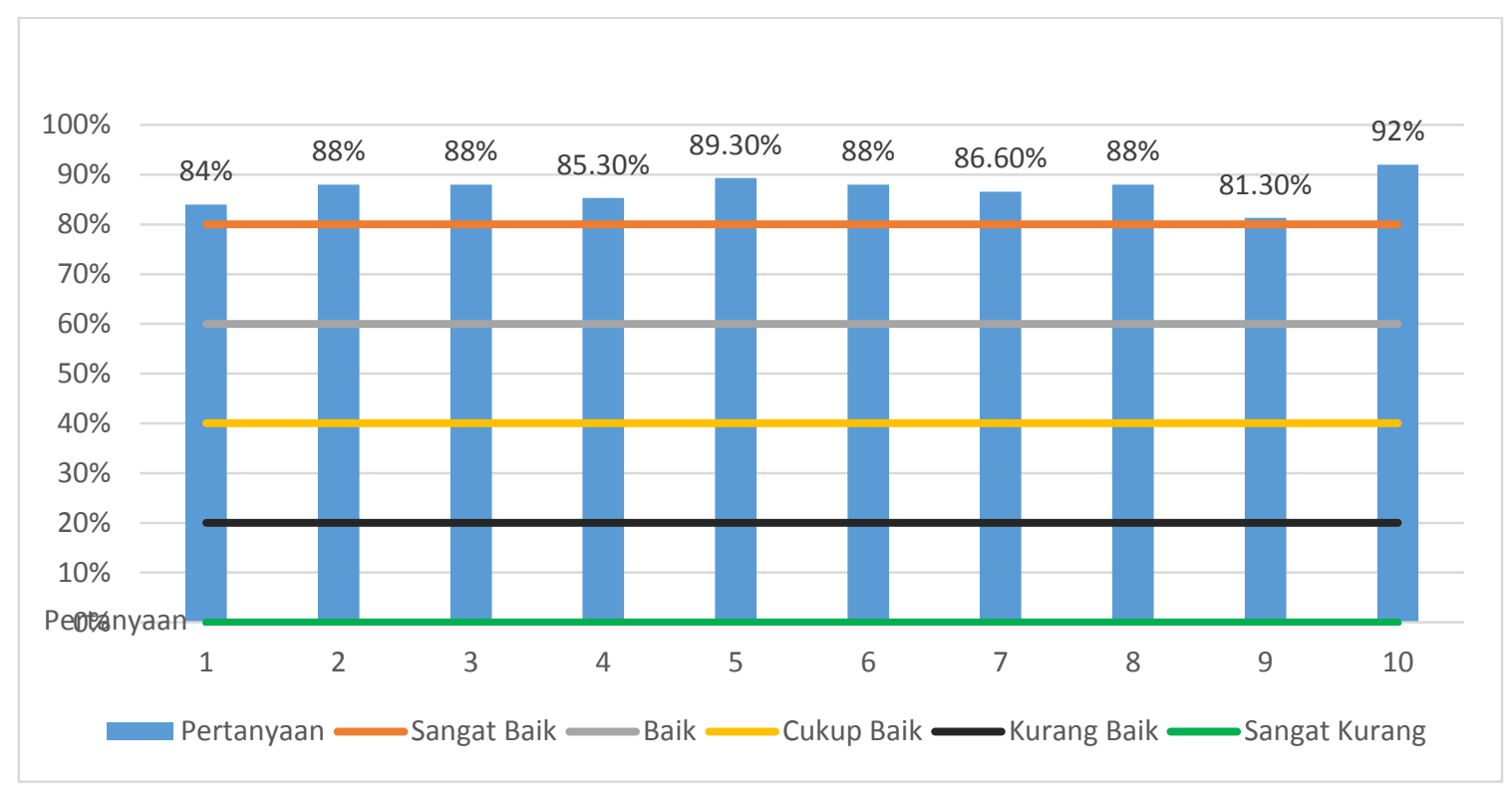

Gambar 11. Hasil Pengujian Kepuasan Pengguna dengan Skala Likert.

\section{Kesimpulan dan Saran}

\section{Kesimpulan}

Kesimpulan dari penelitian ini adalah sebagai berikut:

1 Telah dibangun Pengembangan Sistem Rekrutmen Online dengan menggunakan Framework Laravel untuk membantu pihak UPT (CCED) dalam menghubungkan pencari kerja dan perusahaan dimana pihak UPT Kewirausahaan dan Pengembangan Karir Unila sebagai mitra penghubung.

2 Pengembangan Sistem Rekrutmen Online telah berhasil membuat posting lowongan pekerjaan beserta ketentuan dan syarat yang dibutuhkan.

3 Pengembangan Sistem Rekrutmen Online telah berhasil membuat data pelamar dalam bentuk CV. Dimana dalam melamar pekerjaan CV adalah nilai utama pelamar untuk mendaftar pekerjaan.

\section{Saran}

Saran untuk pengembangan dari penelitian ini adalah sebagai berikut:

1. Sistem dapat memberikan notifikasi apabila perusahaan telah mengumumkan pengumuman lulus seleksi.

2. Sistem dapat terhubung dengan email untuk mengkonfirmasi akun.

3. Sistem dalam waktu lowongan dapat dimulai tidak harus pada saat lowongan pekerjaan dibuat.

\section{DAFTAR PUSTAKA}

[1] Boxall, P., \& Purcell, J. (2003). Strategy and Human Resource Management. Review of Strategy and Human Resource Management, 57(1), 146.

[2] Handayani, V. R., Wijianto, R., \& Anggoro, A. (2018). Sistem Informasi Pendaftaran Seleksi Kerja Berbasis Web pada BKK (Bursa Kerja Khusus) Tunas Insan Karya SMK Negeri 2 Banyumas. Jurnal Evolusi, 6(1).

[3] Irsan, M., Yuliyasni, E., Nufus, K., Afrida, S., \& Ratnasari, E. (2014). Rancangan Aplikasi ERecruitment pada PT. Kalila Indonesia. Seminar Nasional Teknologi Informasi Dan Komunikasi 2014.

[4] Juwita, K. (2013). Analisis Efektivitas Metode Rekrutmen Melalui Social Media.

[5] Miles, R., \& Hamilton, K. (2006). A Pragmatic Introduction to UML (2.0). United States of America: O'Reilly Media. 
[6] Nanda, K. D., \& Prasetya, A. (2017). Efektifitas Penerapan Metode Rekrutmen Online (E- Recruitment). Jurnal Administrasi, 53(1).

[7] O’brien, J. A., \& Marakas, G. M. (2003). Management Information Systems.

[8] Parry, E., \& Tyson, S. (2008). An Analysis of the Use and Success of Online Recruitment. Human Resource Management Journal, 18(3).

[9] Pressman, R. S. (2010). Software Engineering Practitioner's Approach (Seventh). New York: McGrawHill.

[10] Solichin, A. (2010). Pemrograman Web dengan PHP dan MySQL, 1-122. 